\title{
Fizyoterapistlerin İş Yüküne Bağlı Kas-İskelet Sistemi Yaralanmalarının Sağlık Hizmeti Sunumu Üzerine Etkileri
}

\author{
İlknur ARSLAN in $^{1}$, Elif ATICI 國
}

ÖZ

Amaç: İş yüküyle ilişkilendirilen kas-iskelet sistemi yaralanmalarının nitelikli sağlık hizmetinin sürdürülebilirliği, fizyoterapistlerin sağlıklı koşullarda çalışma hakkı üzerindeki etkisini değerlendirmektir.

Gereç ve Yöntemler: Veri toplamada dört bölümden oluşan anket formu kullanıldı. Formun içeriğini bağımsız değişkenler (cinsiyet, yaş, kurum, fizyoterapi alanı, hizmet süresi, haftalık ortalama hastayla direkt temas süresi, günlük ortalama hasta sayısı, grubu), meslekle ilişkili kas-iskelet sistemi yaralanması geçirme durumu, yaralanmayı etkileyen faktörler, geçirilen/geçirilebilecek olası yaralanmanın sağlık hizmeti sunumuna etkisi oluşturmaktadır. 142 anket formu değerlendirildi (Katılım oranı \%61,47). Verilerin analizinde uygun istatistiksel testler kullanıldı.

Bulgular: Katılımcıların \%51,8’i genel fizyoterapi alanında çalışmaktır. En çok A grubu hastalara hizmet verilmektedir (\%92,2). Kas-iskelet sistemini en çok zorlayan hasta grubu sıralaması A, B, C ve D grubudur (\%71). En az bir kez mesleğiyle ilişkili olduğu düşünülen kas iskelet sistemi yaralanması geçirme oranı \%71,6’dır. Yaralanma oranı kadınlarda daha yüksektir $(\% 60,4)$. En çok yaralanma lumbal/sakral bölgede olmaktadır $(\% 60,4)$. Hasta grubunun $(\% 89,8)$, haftalık direkt temas süresinin $(\% 85,6)$, hizmet verilen günlük ortalama hasta sayısının $(\% 76,3)$ yaralanmaları üzerinde etkili olduğu belirtilmiştir. Geçirdiği/geçirebileceği olası bir mesleki yaralanmadan dolayı çalıştığı fizyoterapi alanını değiştirmeyi düşünenlerin ve mesleğini bırakmak isteyenlerin oranı sırasıyla \%49,3, \%28,2'dir. Yaralanma nedeniyle direkt temas süresi $(\% 46,7)$, egzersiz sayısı $(\% 26,4)$, türü $(\% 25,5)$, gözlem süresi $(\% 15,7)$ azalmaktadır. Bu tutum kadınlarda daha fazladır.

Sonuç: Hasta grubu, direkt temas süresinin uzaması, hasta sayısının fazlalığı iş yükünün artmasına ve meslekle ilişkili olduğu düşünülen kas-iskelet sistemi yaralanmasına neden olmaktadır. Bu durum, tıbbi özen yükümlülüğüne dayalı olarak hastanın gereksinimine uygun nitelikli hizmet almasına engel oluşturan ve fizyoterapistlerin sağlıklı koşullarda çalışma hakkını ihlal eden unsurlar olarak kabul edilmelidir.

Anahtar Kelimeler: Fizyoterapistler; iş yükü; sağlık hizmeti sunumu; hasta hakları; iş sağlı̆̆ı.

\section{The Effects of Workload-Related Musculoskeletal Injuries of Physiotherapists on Health Care Delivery}

\begin{abstract}
Aim: Assessing the impact of musculoskeletal injuries associated with workloads on sustainability of qualified healthcare and physiotherapist' on the right to work in healthy conditions.

Material and Methods: Questionnaire consisting of 4 sections was used. Independent variables (gender-ageinstitution-physiotherapy area-service time-weekly average direct contact time-daily average number of patients, patient group), occupational-related musculoskeletal injury, factors affecting injury, effect of previous/potential injury on healthcare constituted the content. 142 questionnaires evaluated (Participation rate 61.47\%). Appropriate statistical tests were used in analyzing data.

Results: 51.8\% work in the field of general physiotherapy. Mostly group A patients are being served (92.2\%). Patient groups ranking that forced musculoskeletal system is A-B-C-D (71\%). Having musculoskeletal injuries at least once considered to be related to profession is $71.6 \%$. Injury rates are higher in women (\%60.4). Most injuries occur in lumbal
\end{abstract}

1 Bursa Uludağ Üniversitesi, Sağlık Bilimleri Enstitüsü, Tıp Tarihi ve Etik A.D., Bursa, Türkiye

2 Bursa Uludağ Üniversitesi Tıp Fakültesi Tıp Tarihi ve Etik A.D., Bursa, Türkiye 
/sacral region (60.4\%). Patient group (89.8\%), weekly average direct contact time (85.6\%), daily average number of patients (76.3\%) were reported to be effective on their injuries. Percentage of those who think about changing physiotherapy area and want to leave their profession with due to an existing/possible occupational injury is $49.3 \%$, 28.2\% respectively. Effects of injuries on healthcare were expressed as direct contact times (46.7\%), number (26.4\%) and type of exercise (25.5\%), observation time (15.7\%). These rates are higher in women.

Conclusion: Patient group, prolonged direct contact and number of patients lead to an increase in workload and cause musculoskeletal injury correlated with profession. This should be considered as factors that violate patient's need to provide quality healthcare based on obligation to healthcare and violate the right of physiotherapists to work under healthy conditions.

Keywords: Physical therapists; workload; delivery of health care; patient's rights; occupational health.

\section{GíRiş}

Dünya Fizik Tedavi Konfederasyonu'nun (WCPT) tanımına göre fizyoterapist, insanların fonksiyonel becerilerini ve hareketlerini iyileştirmelerine, geliştirmelerine ve sürdürmelerine hizmet etmektedir (1). Türkiye'de fizyoterapi alanında lisans eğitimi veren fakülte veya yüksekokullardan mezun olan fizyoterapistlerin (2) görev ve yetkileri, "Sağlık Meslek Mensupları ile Sağlık Hizmetlerinde Çalışan Diğer Meslek Mensuplarının İş ve Görev Tanımlarına Dair Yönetmelik" ile tanımlanmıştır (3). Fizyoterapistler; yaşamın herhangi bir evresinde hareket ve fonksiyonun yaşlanma, yaralanma, hastalık, rahatsızlık, koşullar ya da çevresel faktörler tarafından tehdit edildiği durumlarda koruyucu ve tedavi amaçlı devreye girmektedirler. Sağlığın korunması, tedavi/müdahale, habilitasyon ve rehabilitasyon gibi alanlarında çalışan fizyoterapistler insanların fiziksel, duygusal, psikolojik ve sosyal iyiliklerini göz önüne alarak yaşam kalitelerini yükseltmelerine yardımcı olmaktadırlar (1). Hastanelerde ortopedi ve travmatoloji, nöroloji, pediatrik nöroloji, romatoloji, nöroşirurji, psikiyatri, kardiyoloji, kardiyovasküler cerrahi, gögüs hastalıkları/göğüs cerrahi gibi uzmanlık dallarına ait servislerde ve tüm yoğun bakım servislerinde çalışan fizyoterapistler; fizik tedavi ünitelerinde, yanık ünitelerinde, özel eğitim ve rehabilitasyon merkezlerinde, protez-ortez üretim ve rehabilitasyon merkezlerinde, birinci basamak sağlık hizmeti veren kuruluşlarda, spor kulüplerinde, huzur evlerinde, mesleki rehabilitasyon merkezlerinde ve kaplica merkezlerinde de hizmet sunabilmektedirler. Yükseköğretim Kurulu, Sağlık Bakanlığı, Kalkınma Bakanlığı ve Maliye Bakanlığı görevlilerinden oluşan komisyon tarafından en son yayınlanan "Türkiye'de Sağlık Eğitimi ve Sağlık İnsangücü Durum Raporu”na (4) göre Aralık 2013 itibariyle Türkiye'de aktif çalışan fizyoterapist sayısı 5821 olup 100.000 kişiye düşen aktif çalışan fizyoterapist sayısı 7,7'dir. Avrupa Birliği (AB) ortalaması için bu sayı 80,2'dir. İlgili raporda fizyoterapistlerin \%18,6'sının Sağlık Bakanlığı'nda, \%25,6'sinın özel kurumlarda, \%6,9'unun üniversitelerde ve \%48,9'unun Milli Eğitim Bakanlığı Özel Eğitim ve
Rehabilitasyon Merkezleri, Aile ve Sosyal Politikalar Bakanlığı ve Milli Savunma Bakanlığından oluşan ve diğer olarak isimlendirilen kurumlarda hizmet verdiği bildirilmiştir. Ekonomik İşbirliği ve Kalkınma Örgütü (OECD) verilerine göre ise aynı y1l 2013'te Türkiye'deki fizyoterapist sayıs1 2975 'tir. İlgili verilerde Türkiye'de 2016 yilında 3875 aktif fizyoterapist olduğu ve 100.000 kişiye düşen fizyoterapist sayısının 5 olduğu bildirilmiştir (5). Türkiye Fizyoterapistler Derneği (TFD) 2020 yılında fizyoterapistlerin sayısının yirmi bine ulaşacağını öngörmektedir (6).

Belirli bir niteliğe sahip olan çalışan tarafından, belirli bir sürede yapılması gereken iş miktarı iş yükü olarak tanımlanmaktadır (7). Fiziksel ve zihinsel olarak belirli bir iş yapabilme gücüne sahip olan insanın kapasitesinin üzerinde çalıştırılması durumunda dinlenme ihtiyacı oluşmaktadır. Yeterince dinlenmeyen kişilerde fiziksel ve zihinsel yorgunluğa bağlı olarak meslek hastalıklarıyla karşılaşma ihtimali artmaktadır (8). Türkiye'de çalışan fizyoterapistlerin iş yükünü, Sağlık Uygulama Tebliği'nin (SUT) EK-2/D-2 Listesi'nde yer alan (Fizik Tedavi ve Rehabilitasyon Tanı Listesi) A, B, C ve D grubu hastalıklar oluşturmaktadır (9). İlgili tebliğde ve EK-2/D2'de hasta grupları ile ilgili herhangi bir tanım bulunmamakla birlikte fizik tedavi ve rehabilitasyon tanı listesi oluşturulmuş ve hangi tanının hangi grup (A, B, C, D) altında yer aldığı bilgisi verilmiştir. Tanıya Dayalı İşlem Puanları incelendiğinde zorluk derecesinin de aynı grup sıralamasında olduğu görülmektedir (10). Yaşam süresinin uzaması ve yaşa bağlı gelişen rehabilitasyon gerektiren kronik hastalıkların artışı fizik tedavi ve rehabilitasyon hizmetlerine duyulan gereksinimi de artırmaktadır. Öznel bir yargıyı ifade etse de genel olarak A grubu hastaların (MSS maligniteleri, Parkinson MS, anoksik beyin hasarı, hemipleji, serebral palsi vb.) rehabilitasyonu için ayrılan süre ve iş gücü $B, C$ ve $D$ grubu hastalara göre daha fazladır. Fizyoterapist sayısının yetersiz olduğu kurumlarda fizyoterapistlerin, yalnızca kendileri tarafından tedaviye alınması gereken genellikle nörolojik vakaları oluşturan A ve B grubu hastalara hizmet vermeleri, kimi zaman genellikle ortopedik vakaları oluşturan $\mathrm{C}$ ve $\mathrm{D}$ grubu hastaların hizmetten kismen/tamamen mahrum kalabilmelerine neden olabilmektedir.

İş yüküyle ilgili en büyük sağlık problemleri arasında kas iskelet sistemi problemleri yer almaktadır (11). Kas, tendon, eklem, sinir ve kemikleri etkileyen; ağrı ve fonksiyon kaybina neden olan kas iskelet sistemi hastalıkları (12) aşırı kullanıma bağlı yaralanmalar olarak da isimlendirilmektedir (13). Mesleğe bağlı kas iskelet sistemi yaralanmalarında, yoğun iş yükünün ve kabul edilmiş mesleki monotonluğun yaralanmaların gelişmesinde etkili olabileceği belirtilmekte; tekrarlayıcı hareketler, direkt temas, devam edilen zorlanmış postür primer risk faktörleri içerisinde yer almaktadır (14). Kas iskelet sistemi problemlerinin en önemli nedeni, hasta ile yakın temas gerektiren aktivitelerdir (11). Yapılan çalışmalar, hasta ile direkt temas eden sağlık çalışanlarından özellikle diş hekimlerinin, hekimlerin, fizyoterapistlerin ve hemşirelerin en fazla etkilenen gruplar olduğunu ortaya koymaktadır (15). Tunç (16) tarafından yapılan araştırmada fizyoterapistlerin ve hemşirelerin, hekim ve diş hekimlerine göre kas iskelet 
sistemi bozuklukları yönünden daha fazla risk altında oldukları; fizyoterapistlerdeki bel ağrısı insidansının diğer meslek gruplarına göre daha fazla olduğu bildirilmektedir.

Fizyoterapistler meslekleri gereği sürdürdükleri aktivitelerden (11) ve hastayla birebir temas halinde olmalarından dolayı (17) kas iskelet sistemi yaralanmalarına maruz kalmaktadırlar. Statik ve dinamik çalışma postürleri, ağır kaldırma, tekrarlayıcı fiziksel aktivite, kullanılan araçlar ve ekipmanlar, çalışma organizasyonu ve mental stres kas iskelet sistemi yaralanmalarında ve hastalıklarında fizyoterapistler açısından önemli risk taşımaktadır (16). Mesleğe bağlı kas iskelet sistemi hastalıklarında fizyoterapistler tarafından rapor edilen en yaygın risk faktörleri arasında bilinçsiz postürde çalışma, tekrarlayıcı hareketler, fleksiyon, rotasyon, uzun süre aynı pozisyonda çalışma (14), hasta transferi, hastanın yeniden pozisyonlanması, eklem mobilizasyonu (18) yer almaktadır. Adegoke ve ark. (19) ise gün içerisinde tedavi edilen hasta sayısının fazla olmasının fizyoterapistlerde işe bağlı gelişen kas iskelet sistemi yaralanmalarında en önemli faktör olduğunu rapor etmişlerdir. Hasta sayısı karşısında yeterli nicelikte olmayan fizyoterapistlerin günlük tedavi ettikleri hasta sayısının fazla olması ve hastanelerdeki hastaların çoğunluğunu ciddi rahatsızlığı olan hasta gruplarının oluşturması fizyoterapistlerin kendilerine zarar verebilecekleri kötü postürde çalışmalarına neden olabilmekte; artan iş yükü karşısında fizyoterapistler daha statik postürde çalışmayı tercih edebilmektedirler (14).

Sağlık çalışanlarının çalışma alanlarından dolayı ikinci sıklıkta karşılaştıkları kas iskelet sistemi problemleri yaşam kalitesini etkilemesinin yanı sıra iş kaybına ve ekonomik kayıplara da neden olmaktadır (17). Sağlıklı ve güvenli koşullarda çalışma hakkı ve toplumun gereksinim duyduğu nitelikli sağlık hizmetinin sürdürülebilirliği dikkate alındığında (16) işin öznesi durumunda olan fizyoterapistlerin konuya ilişkin görüşlerine yer verilmesi gerekmektedir. $\mathrm{Bu}$ araştırmayla fizyoterapistlerin değerlendirmesiyle; rehabilitasyon sürecinde hizmet verdikleri hasta sayısının ve grubunun kas iskelet sistemi yaralanmalarında etkili olup olmadığının, var olan ya da olası yaralanmanın sağlık hizmeti sunumuna etkilerinin anlaşılması amaçlanmaktadır. Araştırma konusu mesleğe bağlı kas iskelet sistemi yaralanması nedeniyle fizyoterapistlerin tutumlarındaki olası bir olumsuz değişimin gerek tıbbi özen yükümlülüğünün yerine getirilememesi gerekse de hastaların gereksinim duyduğu hizmeti yeterli ve doğru bir şekilde alamamaları sonucu hasta haklarında ihlale neden olabilmesi riski ve artan işyükünün çalışan sağlığına etkisi bağlamında araştırmaya değerdir.

\section{GEREÇ VE YÖNTEMLER}

Araştırmanın evreni ve örneklemi: Türkiye Fizyoterapistler Derneği'ne üye olan 3567 fizyoterapist araştırma evrenini oluşturmaktadır. Üye listesine derneğin web sayfasından ulaşılmıştır (20).

Örneklem sayısının hesaplanmasında aşağıdaki formül kullanılmıştır: $\quad \mathrm{n}=\frac{N t^{2} p q}{d^{2}(N-1)+t^{2} p q} \quad(\mathrm{p}=0,2 \quad \mathrm{q}=0,8 \quad \mathrm{t}=1,96$ $\mathrm{d}=0,05)$. Bu formüle göre 231 katılımcıya ulaşılması hedeflenmiştir. Araştırmaya katılmayı kabul eden 142 fizyoterapistin verileri değerlendirilmiştir. Katılım oranı \%61,47'dir.

Veri Toplama Aracı: Verilerin toplanmasında konuya ilişkin literatür taraması yapılarak oluşturulan, dört bölümden ve 18 sorudan oluşan anket formu kullanılmıştır. Birinci bölümde bağımsız değişkenlere ait 7 soru (cinsiyet, yaş, çalışılan kurum, fizyoterapi alanı, mesleki hizmet süresi, haftada ortalama hasta ile direkt temas süresi, günlük ortalama hasta sayısı ve grubu) bulunmaktadır. İkinci bölümde meslekle ilişkili olduğunu düşündükleri bir kas iskelet sistemi yaralanması geçirip geçirmediklerini; kas iskelet sistemi yaralanması geçirdilerse zamanını, yaralanma bölgesini, söz konusu yaralanmayı etkileyen faktörlere ilişkin değerlendirmelerini ve yaralanmalarında etken olan faktörleri sıralamalarını içeren birer soru olmak üzere toplam 5 soru bulunmaktadır. Üçüncü bölümde geçirilen ya da olası yaralanmanın sağlık hizmet sunumuna etkilerinin anlaşılması için 3'lü likert tipi (katılıyorum kararsızım - katılmıyorum) şeklinde hazırlanan 2 soru; geçirilen ya da olası bir mesleki yaralanma durumunda çalışılan fizyoterapi alanını değiştirme, mesleği bırakma konusunda "evet-hayır" şeklinde yanıt verebilecekleri 2 soru olmak üzere toplam 4 soru bulunmaktadır. Dördüncü bölümde kas iskelet sistemini zorlayan hasta gruplarının siralanmasının yapılmasinı ve fizyoterapistlerin değerlendirmesiyle, nitelikli bir sağlık hizmet sunumu için çalışılan alana özgü günlük alınabilecek hasta sayısının ve grubunun belirlenmesini isteyen toplam 2 soru yer almaktadir.

Verilerin Toplanması: Araştırma verileri online olarak 17.05.2018- 30.06.2018 tarihleri arasında Türkiye Fizyoterapistler Derneği e-posta grubuna iki defa gönderilerek toplanmıştır.

İstatistiksel Analiz: Verilerin normal dağılıma uygun olup olmadiğı Kolmogorov Smirnov testiyle incelenmiştir. Normal dağılıma uygunluk göstermeyen sürekli değişkenlerde tanımlayıcı istatistikler medyan (Q1-Q3: 1. ve 3. kartil değerleri) olarak verilmiştir. Kategorik değişkenler için tanımlayıcı istatistikler frekans ve yüzde (n; \%) olarak gösterilmiştir. Kategorik değişkenlerin karşılaştırılmasında Pearson Ki-kare (post hoc Bonferroni testi), Fisher Freeman Halton (post hoc Bonferroni testi), Fisher Exact ve Yates'in Süreklilik Düzeltmesi testleri kullanılmıştır. Sürekli değişkenler arasındaki ilişkilerin incelenmesinde Spearman korelasyon katsayısı kullanılmıştır. Anlamlılık düzeyi $\alpha=0,05$ olarak alınmıştır.

Araştırmanın Etik Yönü: Araştırmanın yapılabilmesi için Bursa Uludağ Üniversitesi Tıp Fakültesi Klinik Araştırmalar Etik Kurulu'ndan 06.03.2018 tarih ve 20185/11 karar numarası ile izin alınmıştır. Katılımcıların aydınlatılmış onamları alınmıştır.

\section{BULGULAR}

\section{Kişisel Veriler}

Araştırmaya katılan 142 fizyoterapistin \%53,9'u kadın $(n=76), \% 46,1$ 'i erkektir $(n=65)$. Katılımcıların medyan yaşı (n=134) 30,50 (Q1-Q3: 27-36,25) y1l, medyan hizmet süresi (n=127) 7 (Q1-Q3: 4-12,58) yıldır. Çalıştığ kurumu belirten 136 katılımcının \%26,5'i $(n=36)$ özel eğitim ve rehabilitasyon merkezinde, \%24,3'ü $(n=33)$ devlet hastanesinde, \%20,6's1 $(n=28)$ 
özel hastanede, \%13,2'si $(n=18)$ eğitim ve araştırma hastanesinde, \%5,9'u $(\mathrm{n}=8)$ üniversite hastanesinde çalıştığını bildirirken $\% 9,5^{\prime}$ i $\quad(n=13)$ çalıştığı kurumu diğer (huzurevi, sosyal hizmetler, engelli bakım merkezi, özel klinik vb.) olarak ifade etmiştir. Çalışılan fizyoterapi alanı olarak $(n=139)$ ilk sirada genel fizyoterapi $(n=72$; \%51,8) yer almaktadır. Hastalarla olan haftalık direkt temas süresini belirten katılımcıların $(n=137)$ medyan değeri 35 (Q1-Q3: 20-40) saattir. Tablo 1'de cinsiyete göre verilen yanıtların dağılımı verilmiştir.

Katılimcilarin (n=129) \%92,2'si A grubu (n=118), $\% 9,3$ 'ü B grubu $(n=12)$, \%58,9'u C grubu $(n=76)$ ve $\% 3,1$ 'i D grubu $(n=4)$ hastalara hizmet vermektedir. Bazı katılımcılar birden fazla hasta grubuna hizmet vermekte, bazıları ise her hasta grubuna hizmet vermemektedir. Verilen yanıtlara göre en çok hizmet verilen hasta grubunu sırasıyla A, C, B ve D grubu hastalar oluşturmaktadır. Nitelikli bir sağlık hizmeti sunumu için katılımcıların günlük olarak alınabileceğini düşündükleri hasta grubu siralaması ise A, C, D ve B grubudur (Tablo 2). Hizmet verilen ve nitelikli sağlık hizmeti sunumu için alınması gereken hasta grubuna göre hasta sayısı ile cinsiyet arasında anlamlı bir ilişki bulunmamıștır ( $\mathrm{p} \geq 0$,05; Tablo 3).

Nitelikli bir sağlık hizmeti sunumu için günlük olarak alınabilineceği düşünülen hasta grubu dağılımı ile meslekte geçen süre arasında anlamlı korelasyon olup olmadığına bakıldığında yalnızca $\mathrm{C}$ grubu hasta sayısı ile meslekte geçen süre arasında anlamlılık bulunmuştur $(\mathrm{r}=0,300 ; \mathrm{p}=0,001)$.

2. Meslekle ilişkili olduğu düşünülen bir kas iskelet sistemi yaralanması geçirme durumu

Yanıt veren katılımcılar içerisinde $(n=141) \% 20,4$ 'ü $(n=29)$ bir kere, \%50,7'si $(n=72)$ birden fazla mesleğiyle ilişkili olduğunu düşündüğü bir kas iskelet sistemi yaralanması geçirdiğini ifade etmiştir. Yaralanma geçirenlerin \%60,4'ünü $(n=61)$ kadınlar, \%39,6’sını $(n=40)$ erkekler oluşturmaktadır. Meslekle ilişkili olduğu düşünülen bir kas iskelet sistemi yaralanması geçirme durumu ile cinsiyet arasinda istatistiksel olarak anlamlı bir fark vardır $(\mathrm{p}=0,023)$ Yaralanma geçirdiğini bildiren katılımcıların $(n=101)$ tamamı dikkate alındığında en çok yaralanmaya maruz kalan vücut bölgeleri sirasiyla lumbal/sacral bölge, el/el bileği ve omuzdur (Tablo 1).

En az bir kez yaralanma geçirdiğini bildiren toplam 101 kişiden $88^{\prime}$ 'inin verdiği yanıtlara göre kas iskelet sistemi yaralanmasının medyan değeri mesleğe başladıktan 1,25 (Q1-Q3: 0,50-4) y1l sonra gerçekleşmiştir. Yaralanma geçirilen süre açısından cinsiyet arasında anlamlı bir fark bulunmamıştır ( $\mathrm{p}=0,270$; Tablo 1).

Meslekle ilişkili olduğu düşünülen bir kas iskelet sistemi yaralanması geçiren fizyoterapistlerin çoğunluğu hastalarla olan haftalık direkt temas sürelerinin $(n=77$; \%85,6), hizmet verdikleri günlük ortalama hasta sayılarının $(\mathrm{n}=71 ; \% 76,3)$ ve rehabilitasyon sürecinde yer aldıkları hasta grubunun $(\mathrm{n}=88 ; \% 89,8)$ yaralanmaları üzerinde etkili olduğunu ifade etmişlerdir. Cinsiyete göre verilen yanıtlar değerlendirildiğinde, kadınlar en çok hasta grubunun ( $\mathrm{n=53} \%$ 54,1), erkekler ise en çok hastalarla haftalık direkt temas süresinin $(n=33 ; \% 36,7)$ yaralanmada etkili olduğunu belirtmişlerdir. Verilen yanıtlarla cinsiyet arasında anlamlı bir ilișki yoktur (Tablo 4). Mesleğiyle ilişkili olduğunu düşündükleri bir kas iskelet sistemi yaralanması geçiren ve geçirmeyen fizyoterapistlerin nitelikli bir sağlık hizmeti sunumu için günlük olarak alınabilecek $A, B, C$ ve $D$ grubu hasta sayılarına yönelik yanıtları karşılaştırıldığında ise yalnızca A grubu hasta sayısı bakımından yaralanma geçirme durumu arasında istatistiksel olarak anlamlı bir fark bulunmuştur $(p=0,010)$. Günlük olarak alınabilecek A grubu hasta sayısının medyan (minimum-maksimum) değerleri yaralanma geçirenlerde $(n=89) 3$ (min.maks. $=0$-8) iken yaralanma geçirmeyenlerde $(n=41) 4$ 'tür (min.-maks.=1-10).

3. Meslekle ilişkili olduğu düşünülen bir kas iskelet sistemi yaralanması geçirme durumunun ya da olasılığının fizyoterapistlerin tutumu üzerindeki etkisi Mesleğiyle ilişkili olduğunu düşündüğü bir kas iskelet sistemi yaralanması geçiren fizyoterapistlere, bunun hastalara sundukları hizmete nasıl yansıdığı sorulduğunda katılımcıların yarıya yakını $(n=43 ; \% 46,8)$ hastalarla olan direkt temas sürelerini azalttıklarını ifade etmişlerdir. $\mathrm{Bu}$ tutumu sirasıyla egzersiz sayısını azaltma $(n=24 ; \% 26,4)$, egzersiz türünü azaltma $(n=24 ; \% 25,5)$ ve hastayı egzersiz yaparken gözlemlemeleri gereken süreyi azaltma ( $n=14$; \%15,7) izlemektedir (Tablo 5). Cinsiyete göre "Direkt temas süresini azaltırım" tutumuna verilen yanıtların oran dağılımları arasında anlamlı düzeyde fark vardır $(\mathrm{p}=0,006)$. "Direkt temas süresini azaltırım" tutumuna 'katılıyorum' yanıtını veren kadınların oranı $(\% 76,7)$, ilgili tutuma 'katılmıyorum' yanıtını veren kadınların oranından $(\% 42,5)$ anlamlı düzeyde daha yüksektir $(p<0,05)$. Ancak "Direkt temas süresini azaltırım" tutumuna 'katılıyorum' yanıtını veren erkeklerin oranı $(\% 23,3)$, ilgili tutuma 'katılmıyorum' yanıtını veren erkeklerin oranından $(\% 57,5)$ anlamlı düzeyde daha düşüktür $(\mathrm{p}<0,05)$. Ayrıca kadınlar içinde "Direkt temas süresini azaltırım" tutumuna 'katılıyorum' yanıtını verenlerin oranı (\%60), erkekler içinde ilgili tutuma aynı cevabı verenlerin oranından (\%27) anlamlı düzeyde daha yüksektir $(\mathrm{p}<0,05)$. Ek olarak kadınlar içinde "Direkt temas süresini azaltırım" tutumuna 'katılmıyorum' yanıtını verenlerin oranı (\%30,9), erkekler içinde ilgili tutuma aynı cevabı verenlerin oranından $(\% 62,2)$ anlamlı düzeyde daha düşüktür $(\mathrm{p}<0,05)$.

Cinsiyete göre "Hastamı egzersizlerini yapıyorken gözlemlemem gereken süreyi azaltırım" tutumuna verilen yanıtların oran dağılımları arasında anlamlı düzeyde fark vardır ( $p=0,043)$. Kadınlar içinde "Hastamı egzersizlerini yapıyorken gözlemlemem gereken süreyi azaltırım" tutumuna 'kararsızım' yanıtını verenlerin oranı $(\% 9,6)$, erkekler içinde ilgili tutuma aynı cevabı verenlerin oranından (\%29,7) anlamlı düzeyde daha düşüktür $(p<0,05)$. Cinsiyete göre "Egzersiz türünde bir değişikliğe gitmememe karşın egzersiz sayısını azaltırım” tutumuna verilen yanıtların oran dağılımları arasında anlamlı düzeyde fark vardır $(p=0,036)$. "Egzersiz türünde bir değişikliğe gitmememe karşın egzersiz sayısını azaltırım" tutumuna 'katılıyorum' yanıtını veren kadınların oranı $(\% 79,2)$ aynı tutuma 'kararsızım' yanitını veren kadınların oranından $(\% 42,9)$ anlamlı düzeyde daha yüksektir $(p<0,05)$. Ayrıca "Egzersiz türünde bir değişikliğe gitmememe karşın egzersiz sayısını azaltırım" tutumuna 'katılıyorum' yanıtını veren erkeklerin oranı $(\% 20,8)$ aynı tutuma 'kararsızım' yanıtını veren 
Tablo 1. Katılımcıların kategorik ve sürekli kişisel veri dağılımı

\begin{tabular}{|c|c|c|c|c|}
\hline \multirow{2}{*}{ Kişisel Veriler } & & \multicolumn{2}{|c|}{ Sayı (Yüzde) } & \multirow{2}{*}{ p-değeri } \\
\hline & & Kadın & Erkek & \\
\hline \multirow{6}{*}{ Çalışılan Kurum } & $\begin{array}{l}\text { Özel Eğitim ve } \\
\text { Rehabilitasyon Merkezi }\end{array}$ & $21(29,2)$ & $15(23,4)$ & \multirow{6}{*}{$0,163^{1}$} \\
\hline & Devlet Hastanesi & $19(26,4)$ & $14(21,9)$ & \\
\hline & Özel Hastane & $13(18,1)$ & $15(23,4)$ & \\
\hline & $\begin{array}{l}\text { Eğitim ve Araştırma } \\
\text { Hastanesi }\end{array}$ & $9(12,5)$ & $9(14,1)$ & \\
\hline & Üniversite Hastanesi & $1(1,4)$ & $7(10,9)$ & \\
\hline & $\begin{array}{l}\text { Diğer (huzurevi, sosyal } \\
\text { hizmetler, engelli bakım } \\
\text { merkezi, özel klinik) }\end{array}$ & $9(12,5)$ & $4(6,3)$ & \\
\hline \multirow{5}{*}{ Fizyoterapi alanı } & Genel fizyoterapi & $35(46,7)$ & $37(57,8)$ & \multirow{5}{*}{$0,589^{2}$} \\
\hline & Pediatrik rehabilitasyon & $22(29,3)$ & $15(23,4)$ & \\
\hline & Nörolojik rehabilitasyon & $8(10,7)$ & $5(7,8)$ & \\
\hline & $\begin{array}{l}\text { Ortopedik } \\
\text { rehabilitasyon }\end{array}$ & $7(9,3)$ & $3(4,7)$ & \\
\hline & $\begin{array}{l}\text { Diğer (yoğun bakım, } \\
\text { yanık ünitesi, obezite) }\end{array}$ & $3(4)$ & $4(6,3)$ & \\
\hline \multirow{2}{*}{$\begin{array}{l}\text { Mesleğiyle ilişkili } \\
\text { olduğu düşünülen } \\
\text { bir kas iskelet } \\
\text { sistemi } \\
\text { yaralanması } \\
\text { geçirme durumu }\end{array}$} & Evet* & $61(80,3)$ & $40(61,5)$ & \multirow{2}{*}{$0,023^{3}$} \\
\hline & Hayır & $15(19,7)$ & $25(38,5)$ & \\
\hline \multirow{10}{*}{$\begin{array}{l}\text { Yaralanmaya } \\
\text { maruz kalan } \\
\text { vücut bölgeleri }\end{array}$} & Boyun & $15(24,6)$ & $10(2,5)$ & \multirow{10}{*}{-} \\
\hline & Omuz & $26(42,6)$ & $14(35)$ & \\
\hline & Kalça & $4(6,6)$ & $2(5)$ & \\
\hline & Torasik Bölge & $7(11,5)$ & $9(22,5)$ & \\
\hline & Dirsek & $6(9,8)$ & $2(5)$ & \\
\hline & Diz & $9(14,8)$ & $15(37,5)$ & \\
\hline & Lumbal / sakral bölge & $38(62,3)$ & $23(57,5)$ & \\
\hline & El / el bileği & $32(52,5)$ & $19(47,5)$ & \\
\hline & Ayak / ayak bileği & $1(1,6)$ & $1(2,5)$ & \\
\hline & Toplam & $61(60,4)$ & $40(39,6)$ & \\
\hline \multirow{2}{*}{\multicolumn{2}{|c|}{ Hizmet Süresi }} & \multicolumn{2}{|c|}{ Medyan (Q1-Q3) } & p-değeri \\
\hline & & $7,83(4-14)$ & $6,50(3-11)$ & $0,421^{4}$ \\
\hline \multicolumn{2}{|c|}{ Hastalarla olan haftalık direkt temas süresi } & $37,50(20-40)$ & $35(15,12-40)$ & $0,666^{4}$ \\
\hline \multicolumn{2}{|c|}{$\begin{array}{l}\text { Mesleğe başladıktan sonra yaralanma } \\
\text { geçirilen süre }\end{array}$} & $2(0,37-5)$ & $1(0,62-2,25)$ & $0,270^{4}$ \\
\hline
\end{tabular}

Tablo 2. Fizyoterapistlerin cinsiyetine göre günlük olarak hizmet verilen ve nitelikli bir sağlık hizmeti sunumu için günlük olarak alınabileceği düşünülen hasta gruplarının dağılımı

\begin{tabular}{|c|c|c|c|}
\hline \multirow{2}{*}{$\begin{array}{c}\text { Günlük olarak hizmet verilen hasta } \\
\text { grubu* }\end{array}$} & \multicolumn{2}{|c|}{ Sayı (Yüzde) } & \multirow{2}{*}{ p-değeri } \\
\hline & Kadın & Erkek & \\
\hline $\mathrm{A}$ & $61(91)$ & $57(93,4)$ & $0,747^{1}$ \\
\hline $\mathrm{B}$ & $8(11,9)$ & $4(6,6)$ & $0,459^{2}$ \\
\hline $\mathrm{C}$ & $36(53,7)$ & $40(65,6)$ & $0,237^{2}$ \\
\hline $\mathrm{D}$ & $4(6)$ & $0(0)$ & $0,121^{1}$ \\
\hline \multirow{2}{*}{$\begin{array}{l}\text { Günlük olarak hizmet verilmesi } \\
\text { gerektiği düşünülen hasta grubu* }\end{array}$} & \multicolumn{2}{|c|}{ Sayı (Yüzde) } & \\
\hline & Kadın & Erkek & p-degeri \\
\hline $\mathrm{A}$ & $66(97,1)$ & $58(95,1)$ & $0,667^{1}$ \\
\hline $\mathrm{B}$ & $20(29,4)$ & $9(14,8)$ & $0,075^{2}$ \\
\hline $\mathrm{C}$ & $56(82,4)$ & $46(75,4)$ & $0,453^{2}$ \\
\hline $\mathrm{D}$ & $24(35,3)$ & $17(27,9)$ & $0,475^{2}$ \\
\hline
\end{tabular}

* SUT EK2/D2'ye göre hasta grupları (A: A grubu hasta, B: B grubu hasta, C: C grubu hasta, D: D grubu hasta),

${ }^{1}$ Fisher Exact test, ${ }^{2}$ Yates'in Süreklilik Düzeltmesi testi 
Tablo 3. Günlük olarak hizmet verilen ve nitelikli bir sağlık hizmeti sunumu için günlük olarak alınabileceği düşünülen hasta grubuna göre hasta sayısının dağılımı

\begin{tabular}{|c|c|c|c|}
\hline \multirow{2}{*}{$\begin{array}{c}\text { Günlük olarak hizmet verilen hasta } \\
\text { grubu* }\end{array}$} & \multicolumn{2}{|c|}{ Medyan (Q1-Q3) } & \multirow{2}{*}{ p-değeri ** } \\
\hline & Kadın & Erkek & \\
\hline ( & $\begin{array}{c}5 \\
(2-8) \\
\end{array}$ & $\begin{array}{c}6 \\
(3-8)\end{array}$ & 0,464 \\
\hline $\mathrm{C}$ & $\begin{array}{c}1 \\
(0-6)\end{array}$ & $\begin{array}{c}4 \\
(0-8)\end{array}$ & 0,126 \\
\hline \multirow{2}{*}{$\begin{array}{l}\text { Günlük olarak hizmet verilmesi } \\
\text { gerektiği düşünülen hasta grubu* }\end{array}$} & \multicolumn{2}{|c|}{ Medyan (Q1-Q3) } & n-deб̆eri** \\
\hline & Kadın & Erkek & p-aegeri" \\
\hline 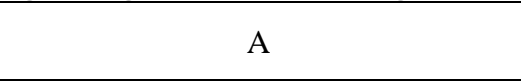 & $\begin{array}{c}3 \\
(2-4) \\
\end{array}$ & $\begin{array}{c}4 \\
(2-6) \\
\end{array}$ & 0,061 \\
\hline $\mathrm{C}$ & $\begin{array}{c}4 \\
(2-5,75)\end{array}$ & $\begin{array}{c}4 \\
(0,50-6)\end{array}$ & 0,373 \\
\hline
\end{tabular}

(Q1-Q3): 1. ve 3. kartil değerleri, * SUT EK2/D2'ye göre hasta grupları (A: A grubu hasta, C: C grubu hasta) **Mann-Whitney U testi

Tablo 4. Mesleğiyle ilişkili olduğu düşünülen bir kas iskelet sistemi yaralanması geçiren fizyoterapistlere göre yaralanmaya etki eden faktörlerin cinsiyete göre dağılımı

\begin{tabular}{|c|c|c|c|c|c|c|c|}
\hline \multirow{2}{*}{$\begin{array}{c}\text { Yaralanmaya etki eden } \\
\text { faktörler }\end{array}$} & \multicolumn{2}{|c|}{$\begin{array}{l}\text { Katılıyorum } \\
\text { Sayı (Yüzde) } \\
\end{array}$} & \multicolumn{2}{|c|}{$\begin{array}{c}\text { Kararsızım } \\
\text { Sayı (Yüzde) } \\
\end{array}$} & \multicolumn{2}{|c|}{$\begin{array}{c}\text { Katılmıyorum } \\
\text { Sayı (Yüzde) } \\
\end{array}$} & \multirow[b]{2}{*}{ p-değeri * } \\
\hline & Kadın & Erkek & Kadın & Erkek & Kadın & Erkek & \\
\hline $\begin{array}{l}\text { Hastalarla olan haftalık direkt } \\
\text { temas süresi etkilidir }{ }^{1}\end{array}$ & $44(48,9)$ & $33(36,7)$ & $6(6,7)$ & $1(1,1)$ & $2(2,2)$ & $4(4,4)$ & $0,176^{*}$ \\
\hline $\begin{array}{l}\text { Günlük ortalama hasta sayısı } \\
\text { etkilidir }{ }^{2}\end{array}$ & $43(46,2)$ & $28(30,1)$ & $8(8,6)$ & $4(4,3)$ & $5(5,4)$ & $5(5,4)$ & $0,770^{*}$ \\
\hline $\begin{array}{l}\text { Rehabilitasyon sürecinde yer } \\
\text { alınan hasta grubu etkilidir }{ }^{3}\end{array}$ & $53(54,1)$ & $35(35,7)$ & $2(2)$ & $0(0)$ & $4(4,1)$ & $4(4,1)$ & $0,537^{*}$ \\
\hline
\end{tabular}

${ }^{1} \mathrm{n}=90,{ }^{2} \mathrm{n}=93,{ }^{3} \mathrm{n}=98, *$ Fisher Exact test

Tablo 5. Meslekle ilişkili olduğu düşünülen bir kas iskelet sistemi yaralanması geçiren ve geçirmemiş olan fizyoterapistlerin geçirilen ya da olası yaralanmaya ilişkin tutumlarının cinsiyete göre dağılımı

Meslekle ilişkili olduğu düşünülen bir kas iskelet sistemi yaralanması geçiren fizyoterapistlerin yaralanmaya ilişkin tutumlarının cinsiyete göre dağılımı

\begin{tabular}{|c|c|c|c|c|c|c|c|}
\hline \multirow[b]{2}{*}{ Tutum } & \multicolumn{2}{|c|}{$\begin{array}{l}\text { Katılıyorum } \\
\text { Sayı (Yüzde) }\end{array}$} & \multicolumn{2}{|c|}{$\begin{array}{c}\text { Kararsızım } \\
\text { Sayı (Yüzde) }\end{array}$} & \multicolumn{2}{|c|}{$\begin{array}{c}\text { Katılmıyorum } \\
\text { Sayı (Yüzde) }\end{array}$} & \multirow{2}{*}{ p-değeri * } \\
\hline & Kadın & Erkek & Kadın & Erkek & Kadın & Erkek & \\
\hline $\begin{array}{l}\text { Hastalarla olan direkt temas } \\
\text { süremi azalttım }{ }^{1} \text {. }\end{array}$ & $33(35,9)$ & $10(10,9)$ & $5(5,4)$ & $4(4,3)$ & $17(18,5)$ & $23(25)$ & 0,006 \\
\hline $\begin{array}{l}\text { Hastamı egzersizlerini } \\
\text { yapıyorken gözlemlemem } \\
\text { gereken süreyi azalttım. }\end{array}$ & $10(11,2)$ & $4(4,5)$ & $5(5,6)$ & $11(12,4)$ & $37(41,6)$ & $22(24,7)$ & 0,043 \\
\hline $\begin{array}{l}\text { Egzersiz türünde bir değişikliğe } \\
\text { gitmememe karşın egzersiz } \\
\text { sayısını azalttım. }\end{array}$ & $19(20,9)$ & $5(5,5)$ & $9(9,9)$ & $12(13,2)$ & $25(27,5)$ & $21(23,1)$ & 0,036 \\
\hline 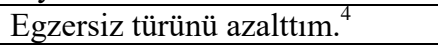 & $14(14,9)$ & $10(10,6)$ & $16(17)$ & $11(11,7)$ & $25(26,6)$ & $18(19,1)$ & 0,996 \\
\hline \multicolumn{8}{|c|}{$\begin{array}{c}\text { Meslekle ilişkili olduğu düşünülen bir kas iskelet sistemi yaralanması geçirmemiş olan fizyoterapistlerin olası } \\
\text { yaralanmaya ilişkin tutumlarının cinsiyete göre dağılımı }\end{array}$} \\
\hline \multirow{3}{*}{ Olası Tutum } & \multicolumn{2}{|c|}{ Katılyyorum } & \multicolumn{2}{|c|}{ Kararsızım } & \multirow{2}{*}{\multicolumn{2}{|c|}{$\begin{array}{c}\text { Katılmıyorum } \\
\text { Sayı (Yüzde) }\end{array}$}} & \multirow{3}{*}{ p-değeri ** } \\
\hline & \multicolumn{2}{|c|}{ Sayı (Yüzde) } & \multicolumn{2}{|c|}{ Sayı (Yüzde) } & & & \\
\hline & Kadın & Erkek & Kadın & Erkek & Kadın & Erkek & \\
\hline $\begin{array}{l}\text { Hastalarla olan direkt temas } \\
\text { süremi azaltırım. }\end{array}$ & $4(14,3)$ & $10(35,7)$ & $3(10,7)$ & $2(7,1)$ & $3(10,7)$ & $6(21,4)$ & 0,501 \\
\hline $\begin{array}{l}\text { Hastamı egzersizlerini } \\
\text { yapıyorken gözlemlemem } \\
\text { gereken süreyi azaltırım. }^{6}\end{array}$ & $4(14,8)$ & $1(3,7)$ & $2(7,4)$ & $4(14,8)$ & $4(14,8)$ & $12(44,5)$ & 0,131 \\
\hline $\begin{array}{l}\text { Egzersiz türünde bir değişikliğe } \\
\text { gitmememe karşın egzersiz } \\
\text { sayısını azaltırım. }\end{array}$ & $3(11,1)$ & $5(18,5)$ & $2(7,4)$ & $4(14,8)$ & $4(14,8)$ & $9(33,3)$ & 0,999 \\
\hline Egzersiz türünü azaltırım. $^{8}$ & $3(11,1)$ & $3(11,1)$ & $3(11,1)$ & $2(7,4)$ & $4(14,8)$ & $12(44,4)$ & 0,296 \\
\hline
\end{tabular}


erkeklerin oranından $(\% 57,1)$ anlamlı düzeyde daha düşüktür $(p<0,05)$. Ek olarak kadınlar içinde "Egzersiz türünde bir değișikliğe gitmememe karşın egzersiz sayısını azaltırım" tutumuna 'katılıyorum' yanıtını verenlerin oranı $(\% 35,8)$, erkekler içinde ilgili tutuma aynı cevabı verenlerin oranından $(\% 13,2)$ anlamlı düzeyde daha yüksektir $(\mathrm{p}<0,05)$.

Mesleğiyle ilişkili bir kas iskelet sistemi yaralanması geçirmemiş olan fizyoterapistlere olası bir mesleki yaralanma durumunda bunun hastaya sundukları hizmete nasıl yansıyabileceği sorulduğunda, katılımcıların \%50'si ( $n=14)$ hastalarla olan direkt temas sürelerini azaltabileceğini ifade etmiştir. $\mathrm{Bu}$ tutumu sırasıyla egzersiz sayısını azaltma $(n=8 ; \% 29,6)$, egzersiz türünü azaltma $(n=6 ; 22,2)$ ve hastayı egzersiz yaparken gözlemlemeleri gereken süreyi azaltma $(n=5 ; \% 18,5)$ izlemektedir. Verilen yanıtlarla cinsiyet ve fizyoterapi alanı arasında istatistiksel olarak anlamlı bir ilişki bulunmamıştır (Tablo 5). Yaralanma geçirmeyenlerin geçirenlere göre direkt temas süresini azaltma (\%50), gözlemlenen süreyi azaltma $(\% 18,5)$ ve egzersiz sayısını azaltma $(\% 29,6)$ tutumunun daha yüksek oranda olduğu görülmektedir ancak anlamlı farklılık bulunmamaktadır. $\mathrm{Bu}$ oranlar yaralanma geçirmiş olan katılımcılarda sirasiyla \%46,8, \%15,7 ve \%26,4'tür.

Araştırmaya katılan fizyoterapistlerin $(n=142) \% 49,3$ 'ü $(n=70)$ geçirdiği veya olası bir mesleki yaralanma sonucu çalıştığı fizyoterapi alanını değiştirme isteğini ifade etmiştir. Verilen yanıtların dağılımı bakımından cinsiyet $(\mathrm{p}=0,559)$, çalışılan alan $(\mathrm{p}=0,203)$ ve meslekte geçen süre $(p=0,419)$ arasında istatistiksel olarak anlamlı bir fark bulunmamaktadır. Geçirilen veya olası bir mesleki yaralanmanın mesleği bırakma isteğine neden olmadığını ifade eden fizyoterapistlerin oran1 \%71,8'dir $(n=102)$. Verilen yanıtların dağ 1 lımı bakımından cinsiyet $(\mathrm{p}=0,440)$ ve çalışılan alan $(p=0,405)$ arasında istatistiksel olarak anlamlı bir fark yokken meslekte geçen süre arasında istatistiksel olarak anlamlı bir fark bulunmuştur $(p=0,028)$. Mesleği bırakmak isteyenlerin meslekte geçen sürelerinin medyan değeri 6 (Q1-Q3: 2,70-8,46) iken bırakmak istemeyenlerin meslekte geçen sürelerinin medyan değeri 7,91'dir (Q1-Q3: 4-14).

Fizyoterapistlerin kas iskelet sistemini zorlayan ve en riskli olandan başlayarak hasta gruplarını sıralamaları istendiğinde $(\mathrm{n}=124)$ ilk üç sıralama ve oranları sırasıyla A-B-C-D (\%71), A-C-B-D (\%13,7), A-C-D-B (\%4)'dir. Katılımcılar tarafindan yapılan 12 farklı sıralama, ilk ikisi (ABCD-ACBD) ve diğerleri olacak şekilde yeniden gruplandırılarak değerlendirildiğinde cinsiyet $(p=0,279)$, çalışılan fizyoterapi alanı $(\mathrm{p}=0,260)$, meslekte geçen süre $(p=0,156)$, mesleğiyle ilişkili olduğunu düşündükleri bir kas iskelet sistemi yaralanması geçiren ve geçirmeyen fizyoterapistler arasında $(\mathrm{p}=0,474)$ istatistiksel olarak anlamlı bir fark bulunmamıştır.

\section{TARTIŞMA}

Türkiye'de yapılan, özel eğitim ve rehabilitasyon merkezlerinde çalışan öğretmenlerin, fizyoterapistlerin ve psikologların katıldığ 1 bir araştırma sonucuna göre çalışma ortamında iş yükünü en ağır olarak belirten grup fizyoterapistler olmuştur (21). Uluslararası literatür taramasında fizyoterapistlerde işten kaynaklanan kas iskelet sistemi problemlerine (yaralanma, ağrı, ağrı ya da rahatsızlık, hastalık, bozukluk) ilişkin prevalansın \%32 ile \%95 arasında değiştiği görülmektedir (22-33). Salik ve Özcan'ın (34) yapmış olduğu araştırmada Türkiye'de işten kaynaklanan kas iskelet sistemi yaralanması prevalansı $\% 85$ olarak bildirilmiştir. $\mathrm{Bu}$ oran araştırma sonucumuzda \%71,6 olarak bulunmuştur. Cromie ve ark. (24) tarafından yapılan araştırma sonucuna göre yaralanma bölgeleri içerisinde çoğu bölgede kadınlar ve erkekler arasında fark bulunmamakla birlikte boyun, el/el bileği ve başparmak yaralanma oranları erkeklerde daha yüksektir. $\mathrm{Bu}$ araştırmadan farklı olarak ișten kaynaklanan kas iskelet sistemi hastalığının kadınlarda erkeklerden daha yüksek olduğunu gösteren (28) ve bel ağrısının kadın, genç ve rehabilitasyon ortamlarında çalıșan fizyoterapistlerde daha yüksek prevalansa sahip olduğunu bildiren (31) çalışmalar da bulunmaktadır. Tsekoura ve ark. (33) cinsiyetler arasında anlamlı farkın olduğunu, boyun, omuz, dirsek ve diz bölgesinde yaralanma oranının kadınlarda erkeklerden daha yüksek olduğunu ifade etmişlerdir. Araştırmamızda da mesleğiyle ilişkili olduğunu düşündüğü bir kas iskelet sistemi yaralanması geçiren fizyoterapistlerin oranı kadınlarda $(\% 60,4)$ erkeklerden $(\% 39,6)$ daha yüksek bulunmuştur.

Molumphy ve ark. (35) yaptığı araştırma sonuçlarına göre işten kaynaklanan bel ağrısının başlangıcı fizyoterapistlerin meslek hayatlarının ilk dört yilında, Mierzejewski ve Kumar'a (22) göre siklıkla meslek hayatlarının ilk beş yılında ve 30 yaşından öncedir. Farklı çalışmalarda \%32-47 arasında değişen oranlarda işten kaynaklanan kas iskelet sistemi problemi bildiren fizyoterapistler, hastalığın başlangıcının mezuniyetten sonraki ilk beş yıl içerisinde olduğunu ifade etmektedirler (24-27). Araştırmamızın sonuçları literatürle uyum göstermekte olup fizyoterapistlerin mesleğe başladıktan sonra ortalama ilk bir yıl içerisinde işleriyle ilişkili kas iskelet sistemi yaralanması geçirdikleri görülmektedir. Literatürde fizyoterapistlerde işten kaynaklanan kas iskelet sistemi problemlerinin (yaralanma, ağrı, ağrı ya da rahatsızlık, hastalık, bozukluk) görüldüğü vücut bölgeleri içerisinde ilk sırada bel bölgesi yer almakla birlikte (2329,31-33,35-38) omuz bölgesinin ilk sirada yer aldığ araştırmaya da rastlamak mümkündür (30). Uluslararası literatüre ve araştırma sonuçlarımıza benzer şekilde ulusal literatürde de ilk sırada bel bölgesi problemlerinin yer aldığı görülmektedir $(14,34)$. Araştırmamızdan farklı olarak etkilenen bölgeler içerisinde ikinci sırada boyun bölgesinin yer aldığı çalışmalar bulunmaktadır (14,24,2628,32,33,36,38). Araştırmamızın sonuçları yaralanma bölgeleri içerisinde ilk dörtte bel, el/el bileği, omuz, boyun bölgelerinin yer aldığı Salik ve Özcan'ın (34) araştırma sonuçlarıyla benzerlik göstermektedir. Sıralamaları değişmekle birlikte araştırma sonuçlarımıza benzer şekilde son üçte dirsek, kalça, ayak/ayak bileğinin yer aldığ 1 (33), dirsek bölgesinin en az etkilenen bölgeler içerisinde olduğu saptanan araştırmalar bulunmaktadır $(25,28,33)$.

Uluslararası literatürde işten kaynaklanan kas iskelet sistemi problemleri nedeniyle mesleği bırakma oranı \%111,1 arasında değişmekte olup $(24-26,32)$ yaralanma ya da yaralanma riskinden dolayı mesleğini değiştirmeyi düşünen fizyoterapistlerin oranı ise $\% 8$ olarak ifade edilmiştir (23). Çalıştığı fizyoterapi alanını değiştirenlerin 
oranı ise \%7,7-17,7 arasında değişmektedir (24,32). Türkiye'de yapılan iki araştırmanın sonuçlarına göre çalıştığı alanı ya da departmanı değiştirmeyi düşünenlerin oranı sırasıyla $\% 64$ ve $\% 20,4$ olarak bulunmuştur $(14,34)$. Literatürle karşılaştırıldığında bulgularımıza göre geçirdiği veya olası bir mesleki yaralanmadan dolayı fizyoterapi alanını değiştirme isteği oranı (\%49,3) yurtdışı verilerinden yüksek, yurtiçi verileri ile uyumludur. Mesleğini bırakma isteği oranı $(\% 28,2)$ ise yurtdışı verilerinden yüksektir. Yüz bin kişiye düşen aktif çalışan fizyoterapist sayısının AB ortalamasından düşük olması (4), dolayısıyla Türkiye'de çalışan fizyoterapisterin iş yükünün batılı meslektaşlarından daha fazla olması bu farklılı̆̆ın nedenleri arasında sayılabilir.

İş yükü ile ilintili olarak değerlendirilebilecek literatürde ulaşılan sonuçlara göre fizyoterapistler bir gün içerisinde hizmet sundukları hasta sayısının fazla olmasını kas iskelet sistemi problemlerinde mesleki risk faktörü olarak görmektedirler. $\mathrm{Bu}$ oran $\% 50$ ile $\% 83,5$ arasinda değişmektedir (19,25-27,32). Araştırma sonuçlarımıza göre de yaralanma geçirdiğini bildiren fizyoterapistlerden \%76,3'ü günlük olarak aldıkları ortalama hasta sayılarının yaralanmaları üzerinde etkili olduğunu ifade etmişlerdir. $\mathrm{Bu}$ sonuç literatürle uyumludur. Ayrıca $\% 85,6$ 's1 hastalarla olan haftalık direkt temas süresini diğer bir etken olarak ifade etmişlerdir. Sonuçlarımızda fizyoterapistlerin günlük olarak aldıkları A grubu hasta sayısı, nitelikli bir sağlık hizmet sunumu için alınabileceğini ifade ettikleri A grubu hasta sayısından fazladir (Tablo 3) ve kas iskelet sistemini en fazla zorladığını belirttikleri hasta grubunu da yine A grubu hastalar oluşturmaktadır. Araştırmamızda yaralanma geçirdiğini bildiren fizyoterapistlerden \%89,8’i rehabilitasyon sürecinde yer aldıkları hasta grubunun yaralanmaları üzerinde etkili olduğunu ifade etmiştir.

Bel ağrısı olan fizyoterapistlerin verdikleri hizmetin bel ağrısından anlamlı şekilde olumsuz yönde etkilendiğini (29), işten kaynaklanan kas iskelet sistemi bozukluğunun fizyoterapistlerin yaşam kalitelerini ve iş yeri stresini olumsuz yönde etkilediğini bildiren (30) çalışmalar bulunmaktadır. Yunan fizyoterapistler üzerinde yapılan bir araştırmada, işten kaynaklanan kas iskelet sistemi ağrıs1 ya da rahatsızlığı yüksek prevalans göstermesine (\%95) rağmen yalnızca \%12,8'inin yaralanmadan kurtulmak için istirahat aldığı bildirilmiştir (33). Fizyoterapistlerin mesleki uygulamalara ilişkin yaralanmadan kaçınmak için tercih ettikleri tutumlar içerisinde manuel terapi yerine elektroterapi tekniklerinin kullanılması $(24,32)$, özellikle üst ekstremite problemleri olanların fizyoterapi uygulamalarını modifiye etmesi (26), tedavi planının değiştirilmesi ve rahatsızlığa neden olmayacak tekniklerin seçilmesi (32) yer almaktadır. Mesleği ile ilişkili olduğunu düşündüğü bir kas iskelet sistemi yaralanması geçiren fizyoterapistlerin hastalarla olan direkt temas sürelerini k1sitlama oranı \%8-31 arasında değişmektedir $(14,23,25,26,34)$. Araştırmamızda ise mesleki yaralanma geçiren fizyoterapistlerin yaralanmadan kaçınmak için hastayla direkt temas süresini azaltma $(\% 46,8)$, egzersiz sayısını azaltma $(\% 26,4)$, egzersiz türünü azaltma $(\% 25,5)$ ve hastayı egzersizlerini yapıyorken gözlemlemeleri gereken süreyi azaltma $(\% 15,7)$ gibi tedavi programını etkileyecek olan tutumları seçtikleri görülmektedir. Mesleğiyle ilişkili bir kas iskelet sistemi yaralanması geçirmemiş olan fizyoterapistler de olası bir mesleki yaralanma durumunda hastalarla olan direkt temas süresini azaltma (\%50), egzersiz sayısını azaltma $(\% 29,6)$, egzersiz türünü azaltma $(\% 22,2)$ ve hastayı egzersiz yaparken gözlemlemeleri gereken süreyi azaltma $(\% 18,5)$ tutumunda bulunabileceklerini ifade etmektedirler. Yaralanma geçiren fizyoterapistlerin hastaya yansıyan tutumları cinsiyete göre incelendiğinde hastayla direkt temas süresini azaltma ve egzersiz sayısını azaltma tutumlarının kadınlarda yüksek olması ve yaralanma geçirmemiş fizyoterapistlerin belirttikleri olası tutumları ile cinsiyet arasında anlamlı ilişki olmaması dikkat çekicidir.

Gözden kaçırılmaması gereken diğer bir konu fizyoterapistlerin iş yüklerini ağır olarak değerlendirdikleri (21), araştırma sonucumuzda da görüldüğü gibi fizyoterapistlerin mesleğiyle ilişkili kas iskelet sistemi problemlerinin prevalansının yüksek olduğu, bir gün içerisinde tedavi edilen hasta sayısının fizyoterapistler tarafından önemli bir mesleki risk faktörü olarak görüldüğü ve bunun yanı sıra OECD verilerine göre, Türkiye'de 100.000 kişiye düşen aktif çalışan fizyoterapist sayısının 2016 yılında 5 olarak bildirildiğidir (5). Hasta sayısı karşısında yeterli nicelikte olmayan fizyoterapistlerin günlük tedavi ettikleri hasta sayısının fazla olması ve hastanelerdeki hastaların çoğunluğunu ciddi rahatsızlığı olan hasta gruplarının oluşturması fizyoterapistlerin kendilerine zarar verebilecekleri kötü postürde çalışmalarına neden olabilmekte; artan iş yükü karşısında fizyoterapistler daha statik postürde çalışmayı tercih edebilmektedirler (14). Mevcut tablo iş yükü nedeniyle çalışan sağlığının bozulması ve bunun bir sonucu olarak hastaların da gereksinimi doğrultusunda hizmet alımının sınırlandırılmasıdır.

Araştırmamızın verilerine göre, katılımcıların \%43,8'i devlet kurumunda, \%46,7'si özel kurumda hizmet vermektedirler. Ülkemizde en son yayınlanan Türkiye'de Sağlık Eğitimi ve Sağlık İnsangücü Durum Raporu'na göre, devlet ve özel kurumlarda çalışan fizyoterapist oranları sırasıyla \%18,6 (sağlık bakanlığına bağlı kurumlar) ve \%25,6'dır (4). Sosyal Güvenlik Kurumu (SGK) ödemeleri devlet kurumlarındaki hizmeti karşılarken özel kurumda hizmet alan hastaların ücret farkını ödemesi gerekmektedir. Bakanlar Kurulunun 16 Eylül 2013 tarihli ve 2013/5385 sayılı Kararnamesi Eki’nde “Kamu idaresi sağlık hizmeti sunucuları dışındaki vakıf üniversiteleri dâhil sözleşmeli sağlık sunucuları, Sağlık Hizmetleri Fiyatlandırma Komisyonu'nca belirlenen sağlık hizmetleri bedelinin en fazla iki katına kadar ilave ücret alabilirler" ifadesine yer verilmiştir (39). Buna göre, SGK anlaşmalı her kurumun yasal olarak \%200'e kadar ücret fark1 talep etme hakk1 bulunmaktadır. Fizyoterapistlerin devlet kurumu ve özel kurumlarda istihdamlarının dağılımı göz önüne alındığında hizmet alımı için sıra beklemek istemeyen hastaların özel kurumları tercih etme zorunlulukları ortaya çıkmaktadır. $\mathrm{Bu}$ şartlar altında hizmete ulaşma ödeme gücü ile ilişkilendirilmektedir. Ücret farkını ödeyebilen ve ödeyemeyen hastalar arasında hizmete ulaşmada eşitlik ilkesi korunamamaktadır.

Türkiye'de yürürlükte olan Hasta Hakları Yönetmeliği’nde bedensel, ruhsal ve sosyal yönden tam 
bir iyilik hali içinde yaşama hakkının, en temel insan hakkı olduğuna ve bunun hizmetin her safhasında göz önünde bulundurulması gerektiğine; herkesin yaşama, maddi ve manevi varlığını koruma ve geliştirme hakkının olduğuna değinilmiştir. Aynı yönetmeliğin 6. maddesinde hastanın sağlık hizmetlerinden ihtiyaçlarına uygun olarak faydalanma hakkına sahip olduğu, 14. maddesinde ise personelin hastanın durumunun gerektirdiği tıbbi özeni göstermesi gerektiği ifade edilmektedir (40). Türkiye Fizyoterapistler Derneği tarafından yayınlanan Etik Prensipler'e göre fizyoterapistler mesleklerini uygularken hastaların hak ve menfaatlerini ön planda tutmalı ve hastaların en uygun ve yeterli fizyoterapi-rehabilitasyon programını uygulamayı amaç edinmelidirler (Madde 13). İlgili düzenlemenin 26. maddesinde ise fizyoterapistlerin başta İnsan Hakları Evrensel Bildirgesi olmak üzere tüm insan hakları belgelerine ve fizyoterapistlikle ilgili ortak kurallara uymakla yükümlü olduklarına değinilmektedir (41). Araştırma sonucunda mesleğiyle ilişkili olduğunu düşündüğü bir kas iskelet sistemi yaralanması geçiren fizyoterapistlerin tutumu ve yaralanma geçirmeyen fizyoterapistlerin olası tutumlarının sağlı hizmet sunumuna yansıması dikkate alındığında, iș yükünü artıran durumların sonucu olarak ifade edebileceğimiz tüm bu davranış değişikliklerinin hastanın gereksinim duyduğu hizmeti yeterli ve doğru şekilde almasını engelleyerek sağlık çalışanının tıbbi özen göstermesi yükümlülüğünün ihlaline neden olacağı söylenebilir.

\section{SONUÇ}

Sağlık çalışanının bilimsel bilgiye dayalı tıbbi standartları sağlayarak, hastanın gereksinimi doğrultusunda hizmet sunması gerekir. $\mathrm{Bu}$ gereklerin yerine getirilmemesi durumu hastanın sağlık hizmetlerinden faydalanma hakkının sağlanamamasına ve istenilmeyen bir sonuç olarak hatalı tıbbi uygulamalara neden olabilmektedir. Hastanın tanı, tedavi ve bakım süreçlerinde bilimsel bilgi ve becerinin uygulanmasını gerektiren tıbbi özen yükümlülüğünün; ihmal, bilgisizlik, yetersizlik gibi durumlarda ihlal edilebileceği gibi makalenin konusunu oluşturan sağlık çalışanının eyleminden bağımsız, hizmetin niteliğini etkileyen iş yükü gibi nedenlere dayalı olarak da ihlal edilebileceği göz ard1 edilmemelidir. Sağlık hizmetinin gereksinimi karşılaması ve kaynakların etkin ve verimli kullanımı için planlamanın doğru yapılması önem arz etmektedir. Ülkemizde yaşam süresinin uzaması ve yaşlı nüfusun artışı fizyoterapi alanına duyulan gereksinimi artırmaktadır. Araştırmamızın sonucuna göre hizmet verilen hasta grubu, hastayla direkt temas süresinin uzaması ve hasta sayısının fazlalığı iş yükünün artmasına ve meslekle ilişkili olduğu düşünülen kas iskelet sistemi yaralanmasina neden olmaktadır. $\mathrm{Bu}$ durum, toplum gereksinimini göz önüne almada yetersiz planlamanın sonuçlarından biri olarak kabul edilebilir. Fizyoterapisterin, meslekle ilişkili yaralanma nedeniyle alan değişikliği ve mesleği bırakma isteğine yurtdışındaki meslektaşlarından daha yüksek oranda katılım göstermeleri de hastaların gereksinimlerinin karşılanmasında planlamada yetersiz kalındığının bir kanıtı olarak değerlendirilmelidir. Ayrıca fizyoterapistlerin devlet kurumlarında istihdamının özel kurumlara göre az olması hizmete ulaşımda eşitliği zedelemektedir. Oysa sağlık alanında insangücü planlaması sağlık çalışanlarının yeterli nitelik ve nicelikte ve dengeli bir dağılımla istihdam edilmesini gerektirmektedir. Buna bağlı olarak gerek hastanın gereksinim duyduğu hizmete erişme noktasında gerekse de fizyoterapistlerin sağlıklı ve güvenli koşullarda çalışma hakkının yerine getirilmesinde sorun ortaya çıkmaktadır. Sağlık alanında gerçekçi, uygulanabilir insangücü planlamasının yapılması bir gerekliliktir.

Fizyoterapistlerin mesleğe bağlı yaralanmasının altındaki nedenlerin derinlemesine araştırılarak çözüm üretilmesi çalışan sağlığının ve hasta haklarının korunmasına destek sağlayacaktır.

\section{KAYNAKLAR}

1. wcpt.org [Internet]. United Kingdom [Updated: 14.10.2016; Cited: 06.01.2019]. Available from: https://www.wcpt.org/what-is-physical-therapy.

2. resmigazete.gov [Internet]. Ankara [Son güncelleme tarihi: 26.04.2011; Erişim tarihi: 06.01.2019]. Erişim adresi: http://www.resmigazete.gov.tr/eskiler/2011/04 /20110426-1.htm.

3. resmigazete.gov [Internet]. Ankara [Son güncelleme tarihi: 22.05.2014; Erişim tarihi: 06.01.2019]. Erişim adresi: http://www.resmigazete.gov.tr/eskiler/2014/05 /20140522-14.htm.

4. saglik.gov [Internet]. Ankara [Son güncelleme tarihi:21.05.2015; Erişim tarihi: 06.01.2019]. Erişim adresi: https://www.saglik.gov.tr/TR,11659/saglikbakanligi-turkiyede-saglik-egitimi-ve-saglikinsangucu-durum-raporu-2014.html.

5. OECD.org [Internet]. [Updated: 08.11.2018; Cited: 06.01.2019]. Available from: https://stats.oecd.org /index.aspx?DataSetCode=HEALTH_STAT.

6. fizyoterapistler.org [Internet]. Ankara [Erişim tarihi: 06.01.2019]. Erişim adresi:

http://www.fizyoterapistler.org/tfd/index.php/en/derne k-hakk-nda/fizyoterapist-kimdir.

7. Karacaoğlu K, Çetin İ. İş yükü ve rol belirsizliğinin çalışanların tükenmişlik düzeyleri üzerine etkisi: Afad örneği. Nevşehir Hacı Bektaş Veli Üniversitesi SBE Dergisi. 2015; 5(1): 46-69.

8. Ayan B. Montaj hattında ergonomik risk unsurlarının incelenmesi: Otomotiv sektörüne yönelik bir uygulama [Uzmanlık Tezi]. Ankara: Çalışma ve Sosyal Güvenlik Bakanlığı Çalışma ve Sosyal Güvenlik Eğitim ve Araştırma Merkezi; 2015.

9. resmigazete.gov [Internet]. Ankara [Son güncelleme tarihi: 01.10.2014; Erişim tarihi: 06.01.2019].Erişim adresi: http:/www.resmigazete.gov.tr/eskiler/2014/10 /20141001-7.htm.

10. resmigazete.gov [Internet]. Ankara [Son güncelleme tarihi: 05.07.2018; Erişim tarihi: 06.01.2019]. Erişim adresi: http://www.resmigazete.gov.tr/eskiler/2018/ 07/20180705M1-1.htm

11. Yakut H, Yakut Y. Türkiye'deki fizyoterapistlerde kas iskelet sistemi yaralanmaları, yorgunluk ve mesleki memnuniyetin değerlendirilmesi. Fizyoterapi Rehabilitasyon. 2011; 22(2): 74-80.

12. Uz Tunçay S, Yeldan İ. Kas iskelet sistemi rahatsızlıklarıyla fiziksel inaktivite ilişkili midir? Ağrı. 2013; 25(4): 147-55. 
13. Duray M, Yağcı N. Pamukkale Üniversitesi Hastaneleri'nde çalışan yardımcı sağlık personelinde kas-iskelet ağrısına etkiyen faktörlerin belirlenmesi. Pamukkale Tıp Dergisi. 2017; 10(2): 144-51.

14. Tekeli H. Farklı alanlarda çalışan fizyoterapistlerde mesleğe bağlı kas iskelet sistemine ait problemlerin değerlendirilmesi [Yüksek Lisans Tezi]. Ankara: Hacettepe Üniversitesi; 2009.

15. Atasavun Uysal S. Ergonomik riskler ve korunma yolları. Editör Oğan H. Sağlık Çalışanlarının Sağlığı 4. Ulusal Kongresi; 2013 Kasım 16-17; Ankara. İstanbul: Türk Tabipleri Birliği Yayınları; 2014. s. 8890.

16. Tunç P. Sağlık çalışanlarında kas iskelet sistemi bozuklukları ile ilgili yaşam kalitesini etkileyen faktörler [Yüksek Lisans Tezi]. Ankara: Başkent Üniversitesi; 2008.

17. Oğuzcan MŞ, Gür G, Karaman GT. Diş hekimlerinde kas ve iskelet sisteminde görülen mesleki dejenerasyonların analizi. A.Ü. Diş Hek. Fak. Derg. 2011; 38(1): 7-13.

18. Campo M, Weiser S, Koenig KL, Nordin M. Workrelated musculoskeletal disorders in physical therapists: A prospective cohort study with 1-year follow-up. Physical Therapy. 2008; 88(5): 608-19.

19. Adegoke BOA, Akodu AK, Oyeyemi AL. Workrelated musculoskeletal disorders among Nigerian Physiotherapists. BMC Musculoskeletal Disorders. 2008; 9: 1-9. doi: 10.1186/1471-2474-9-112

20. fizyoterapistler.org [Internet]. Ankara [Erişim tarihi: 06.02.2018]. Erişim adresi:

http://www.fizyoterapistler.org/tfd/index.php/en/derne k-hakk-nda/tfd-ueye-listesi.

21. Tarakcı E, Tütüncüoğlu F, Tarakcı D. Özel eğitim ve rehabilitasyon alanında çalışan meslek elemanlarının öz-yeterlilik ve tükenmişlik düzeylerinin incelenmesi. Fizyoterapi Rehabilitasyon. 2012; 23(1): 26-35.

22. Mierzejewski M, Kumar S. Prevelance of low back pain among physical therapists in Edmonton, Canada. Disability and Rehabilitation. 1997; 19(8): 309-17.

23. Holder NL, Clark HA, DiBlasio JM, Hughes CL, Scherpf JW, Harding L et al. Cause, prevalence, and response to occupational musculoskeletal injuries reported by physical therapists and physical therapist assistants. Physical Therapy. 1999; 79(7): 642-52.

24. Cromie JE, Robertson VJ, Best MO. Work-related musculoskeletal disorders in physical therapists: Prevalence, severity, risks, and responses. Physical Therapy. 2000; 80(4): 336-51.

25. West DJ, Gardner D. Occupational injuries of physiotherapists in North and Central Queensland. Australian Journal of Physiotherapy. 2001; 47(3): 179-86.

26. Glover W, McGregor A, Sullivan C, Hague J. Workrelated musculoskeletal disorders affecting members of the Chartered Society of Physiotherapy. Physiotherapy. 2005; 91(3): 138-47.

27. Rozenfeld V, Ribak J, Danziger J, Tsamir J, Carmeli E. Prevalence, risk factors and preventive strategies in work-related musculoskeletal disorders among Israeli physical therapists. Physiother. Res. Int. 2010; 15(3): 176-84.

28. Nordin NAM, Leonard JH, Thye NC. Work-related injuries among physiotherapists in public hospitals-a Southeast Asian picture. Clinics. 2011; 66(3): 373-8.

29. Aljairan DN, Al Maeeli HK, Al Fadhel AR, Al Saeedi ES, Shibu L, Rajab E. Prevalence of work-related musculoskeletal disorders amongst physiotherapists in the Kingdom of Bahrain. WCPT Congress; 2015; Singapore; Physiotherapy 2015; 101( Supp. 1 eS54): e54. https://doi.org/10.1016/j.physio.2015.03.172

30. Bae YH, Min KS. Associations between work-related musculoskeletal disorders, quality of life, and workplace stress in physical therapists. Industrial Health. 2016; 54(4): 347-53.

31. Milhem M, Kalichman L, Ezra D, Alperovitch D, Najenson D. Work-related musculoskeletal disorders among physical therapists: A comprehensive narrative review. International Journal of Occupational Medicine and Environmental Health. 2016; 29(5): 735-47.

32. Muaidi QI, and Shanb AA. Prevalence causes and impact of work related musculoskeletal disorders among physical therapists. Journal of Back and Musculoskeletal Rehabilitation. 2016; 29(4): 763-69.

33. Tsekoura M, Kastrinis A, Nomikou E, Kentrou E, Dimitriadis Z. Work-Related Musculoskeletal disorders among Greek Physiotherapists. Musculoskelet. Care. 2017; 15(2): 158-62.

34. Salik Y, Özcan A. Work-related musculoskeletal disorders: A survey of physical therapists in IzmirTurkey. BMC Musculoskeletal Disorders. 2004; 5: 17. doi: 10.1186/1471-2474-5-27.

35. Molumphy M, Unger B, Jensen GM, Lopopolo RB. Physical Therapy. 1985; 65(4): 482-6.

36. Rugelj D. Low back pain and other work-related musculoskeletal problems among physiotherapists. Applied Ergonomics. 2003; 34(6): 635-9.

37. King P, Huddleston W, Darragh AR. Work-related musculoskeletal disorders and injuries: Differences among older and younger occupational and physical therapists. J Occup Rehabil. 2009; 19(3): 274-83.

38. Truszczy'nska A, Scherer A, Grabiec JD. The occurrence of overload at work and musculoskeletal pain in young physiotherapists. Work. 2016; 54(3): 609-16.

39. resmigazete.gov [Internet]. Ankara [Son güncelleme tarihi: 12.10.2013; Erişim tarihi: 06.01.2019]. Erişim adresi: http://www.resmigazete.gov.tr/eskiler/2013/10 /20131012-23.htm.

40. resmigazete.gov [Internet]. Ankara [Son güncelleme tarihi: 01.08.1998; Erişim tarihi: 06.01.2019]. Erişim adresi: http://www.resmigazete.gov.tr/arsiv /23420.pdf.

41. fizyoterapistler.org [Internet]. Ankara [Erişim tarihi: 06.01.2019]. Erişim adresi:

http://www.fizyoterapistler.org/tfd/index.php/en/derne k-hakk-nda/etik-prensipler. 